Kathmandu School of Law Review (KSLR),

Volume 8, Issue 2, 2020, pp 1-15

https://doi.org/10.46985/kslr.v8i2.2149

(C) KSLR, 2020

\title{
Up The Down Staircase: COVID-19 Paves way for Modern Authoritarianism
}

\author{
Nikita Mohan* \& Sanjana Hooda**
}

\begin{abstract}
The global pandemic has shaken the foundational notions that characterize modern society. A host of rights that dignify our life have had to be sacrificed, with the new 'normal' arguably resembling a life reduced to mere existence. Moving into the post-COVID world, we must critically appraise our condition. This essay attempts perspectives on some of the political implications of COVID-19. Through a consideration of ancient philosophies of the likes of Plato and Aristotle, the justification for the institution of the State and why humankind resorts to it, especially in times of crises, has been established. Further consideration of the State's responses to past global crises, of the Spanish Flu and the Influenza Pandemic, help one understand how such an institution often rules out political concerns and motivations, as opposed to serving the 'common good'. This is followed by a discussion of the advent of contemporary authoritarianism in the post-COVID world and on the ideology of populism. The concluding part of this essay deliberates on the political landscape of the post-COVID world. While the authors are in no position to conclusively lay down what the post-COVID world will bring forth, they encourage viewing the pandemic as an opportunity to re-evaluate our political choices and rediscovering the power of mutual aid and solidarity as we refuse to return to 'normal', rather than treating COVID-19 as an irreversible setback for political rights and emancipation. Humankind must thus climb up the down staircase in approaching the post-COVID world.
\end{abstract}

\section{Introduction}

'There is no one in any rule who, in so far as he is a ruler, considers or enjoins what is for his own interest, but always what is for the interest of his subject; to that he looks,

\footnotetext{
* Nikita Mohan is a final year student of law from Jindal Global Law School (JGLS), O. P. Jindal Global University, Sonipat, India. She can be reached at16jgls-nmohan@jgu.edu.in.

** Sanjana Hooda is a final year student of law from Jindal Global Law School (JGLS), O. P. Jindal Global University, Sonipat, India. She can be reached at16jgls-shooda@jgu.edu.in.

The authors wish to thank Professors Raphael Pangalangan and Krishnadeo Singh Chauhan for their comments on an earlier draft. The paper was awarded the 3rd Best Paper in the International Research Paper Writing Competition, which was organized by Kathmandu School of Law Review, Amnesty International Fusion Youth Network, and the Cognition Club.
} 
and that alone he considers in everything which he says and does. ${ }^{11}$

Our world is undergoing massive transformation owing to the unforeseeable circumstances brought forth by the COVID-19 pandemic. As with any global crisis, this pandemic presents numerous issues, ranging from widespread discrimination against ethnic minorities and other marginalized communities ${ }^{2}$ to exacerbation of ableist tendencies in world leaders. ${ }^{3}$ There are ethical concerns regarding the rationing of critical care resources ${ }^{4}$ - with the initial response of governments leaning towards prioritizing those who are healthy and have a good chance of recovering (over the elderly or those with underlying conditions and pre-existing vulnerabilities). ${ }^{5}$ Likewise, we have been forced to confront several pre-existing vulnerabilities of the human condition amid the global pandemic.

It is evident that the world was severely ill-equipped to deal with a global pandemic, and the very foundations that it built its ideologies and beliefs on have been shaken. However, this did not prevent the masses from turning to their respective State heads for a comprehensive solution, which is yet to be found. An ever-increasing trend of dwindling faith in the political system is being witnessed in recent decades. This has been followed by the quest of expanding human rights and establishing them as the toptier component requiring the utmost consideration in the hierarchy of law. COVID-19, however, has led to a breakdown of this belief system, as fundamental human rights are almost willingly being surrendered in pursuit of the 'common good's, giving birth to an almost utilitarian outlook wherein increased control is being handed to the State.

This essay seeks to examine the causes and consequences of increased authoritarianism in the post-COVID world. The first part turns to the likes of Plato and Aristotle as it provides philosophical justifications for the necessity of the State in the organization of human society. It attempts to establish the relevance of ancient philosophy in supplying valuable insights into an uncertain future in the wake of COVID-19. The second part is an analysis of state-led responses in past global crises, of the Spanish Flu and the Influenza Pandemic, and deliberates upon the decision-making processes of governmental authorities. This is followed by a discussion of the advent of

\footnotetext{
Plato, 'The Republic', in Giovanni R. Ferrari (ed), Plato: The Republic (Cambridge Texts in the History of Political Thought), Cambridge University Press, Cambridge, 10th edition, 2012, p. 63.

2 Michelle Bachelet, 'Addressing the disproportionate impact of COVID-19 on minority ethnic communities', Office of the High Commissioner Human Rights (OHCHR) United Nations, 2020, available at https:/ / www.ohchr. $\mathrm{org} / \mathrm{EN} /$ NewsEvents/Pages/DisplayNews.aspx?NewsID=26541\&LangID=E, accessed on 01 August 2020.

3 Shelley Tremain, 'Governing COVID in Brazil: Ableism and Authoritarianism', Biopolitical Philosophy, 2020, available at https://biopoliticalphilosophy.com/2020/04/18/governing-covid-in-brazil-ableism-andauthoritarianism/, accessed on 21 June 2020.

4 Amy L. McGuire et al., 'Ethical Challenges Arising in the COVID-19 Pandemic: An Overview from the Association of Bioethics Program Directors (ABPD) Task Force', The American Journal of Bioethics p.15, volume 20:7, 2020, p. 16.

6 Amitai Etzioni, 'Common Good', in Michael T Gibbons (ed), The Encyclopedia of Political Thought, John Wiley and sons Ltd, 2014, pp. 4-6.
}

5 Tremain (n 4). 
contemporary authoritarianism in the post-COVID world and on the ideology of populism. The concluding part of this essay attempts a perspective on the political landscape of the post-COVID world.

The global pandemic appears to be characterized by the politics of marginalization as governments around the world assume unprecedented control over the lives of their citizens in response to COVID-19. ${ }^{7}$ While we are in no position to conclusively lay down precisely what the post-COVID world will bring forth, we encourage viewing the pandemic as an opportunity to re-evaluate our political choices and the values we cherish most as responsible citizens of the world. The return to a potentially regressive and draconian state of political and economic affairs suggests a shift towards the past. We believe in rediscovering the power of mutual aid and solidarity as we refuse to return to normal, ${ }^{8}$ rather than treating COVID-19 as an irreversible setback for political rights and emancipation. Humankind must thus climb up the down staircase ${ }^{9}$ as we approach the post-COVID world. To this end, it would be useful to inquire into the contributing factors that make COVID-19 a disaster but lie far beyond the virus itself. ${ }^{10}$

\section{A Journey Down Memory Lane: An Examination of the 'State' through Ancient Philosophies}

Since time immemorial, mankind has attempted to determine the characteristics of a seamless system of governance, managing to fashion a plethora of literature on politics and the concept of State. Its origins can be traced back to ancient Greek philosophers such as Socrates, Plato, and Aristotle. ${ }^{11}$ The idealist conceptualization of a State was popularized by Plato, and his ideals have survived over two centuries, as many of the current nation-States have been built upon those very ideals. ${ }^{12}$ However, the contrasting Realist beliefs of his successor Aristotle must also be credited for achieving the same. ${ }^{13}$ Many of the existing political philosophies currently at play in the contemporary world seem to strike a balance between the two.

Plato's idealist State (one may even label it as utopian) would be governed at the behest of a benevolent ruler-selfless and wise. Plato's ruler can be signified through a man

Eduardo J. Gómez \& Sandro Galea, 'Politics May Kill Us, Not the Coronavirus', Think Global Health, 2020, available at https://www.thinkglobalhealth.org/article/politics-may-kill-us-not-coronavirus, accessed on 20 June 2020.

8 Max Haiven, 'Postscript: After the pandemic - against the vindictive normal', in Revenge Capitalism: The Ghosts of Empire, the Demons of Capital, and the Settling of Unpayable Debts, Pluto Press, London, 2020, pp. 204-208.

9 The phrase 'up the down staircase' means using one's failure or shortcomings to succeed. It has been used by us in the context of COVID-19, which also explains the title of this essay.

10 Vicanne Adams, 'Disasters and Capitalism... and COVID-19', Somatosphere, 2020, available at http:// somatosphere.net/2020/disaster-capitalism-covid19.html/, accessed on 22 June 2020.

11 Michael Gagarin \& Paul Woodruff (eds), Early Greek Political Thought from Homer to the Sophists, Cambridge University Press, Cambridge, 1995, p. 23.

12 R. S. Bluck, 'Plato's 'Ideal' State', The Classical Quarterly p.166, volume 9:3-4, 1959, pp. 166-168.

13 Olivera Mijuskovic, 'Aristotle's concept of the state', Socrates p.13, volume 4:4, 2016, p. 18. 
as close to perfection as was humanly possible. An ideal State runs on a government wherein no interests could be placed above those of the citizens- the common good and collective prosperity. Such a state would be termed as an 'aristocracy' and was the most favored by Plato. ${ }^{14} \mathrm{He}$ did come up with alternatives, such as a 'timocracy' and an 'oligarchy'; albeit inferior to aristocracy, but which could be viewed as more realistic in terms of application. Timocracy would be the result of the degeneration of aristocracy, wherein in addition to a virtuous rule, the timocrat would also be invested in the cultivation of self-profit. Subsequently, an 'oligarchy' would be formed from the degeneration of timocracy, creating the binary between the rich and the poor- as the profitable timocratic regime would further supplement the desire for accumulating wealth with an increasing gap between the rich government and its poor subjects. ${ }^{15}$

It is safe to say that most contemporary governments are possibly a mixture of the two degenerates of aristocracy, and self-interest exists in possibly every system of governance in the world today.

Aristotle's realist State is an amalgamation of Plato's beliefs, barring the fact that he attributed self-interest as an inherent characteristic of human beings, and therefore of a ruler's value system. ${ }^{16} \mathrm{He}$ labelled this to be a form of 'egoism' ${ }^{17}$, prevalent in many of his works elaborating on the State. However, he did suggest that the web of interests must have a purpose - to ensure a meaningful and productive life for everyone. ${ }^{18} \mathrm{He}$ coined the term 'politeia' as being that ideal form of government that facilitates the participation of the public in the political process at large, guided by a Constitution. ${ }^{19}$

A noticeable similarity between the teacher-student duo is their contempt for democracy as a form of governance. At the time when their philosophy was laid down, the cracks in Athenian democracy had started to plague the city-state. ${ }^{20}$ Increasing discontent on the part of the rulers and commoners alike was being witnessed. ${ }^{21}$ Democracy as a form of Government was lent a significant part of the blame, as handing the power to rule to the commoners instead of well-educated or virtuous rulers resulted in illinformed decisions. ${ }^{22}$ The two philosophers believed democracy to be a harbinger of

\footnotetext{
$14 \quad$ Ferrari (n 1), p. 423.

15 Ibid, p. xix.

16 Robert C. Bartlett \& Susan D. Collins (eds), Aristotle's Nicomachean Ethics, University of Chicago Press, Chicago, 2011, p. 1166a15-23.

17 Carolyn Ray, 'Egoism in Aristotle's Nicomachean Ethics', Independent Study on Aristotle's Nicomachean Ethics, Indiana University, 1989, available at https://enlightenment.supersaturated.com/essays/text/carolynray/ aristotleegoism.html, accessed on 03 August 2020.

18 Mijuskovic (n 13), p. 18.

19 Aristotle, 'The Politics', in H. W. C. Davis (ed), Aristotle's Politics, Oxford: At the Clarendon Press, London, 1805, pp. III.1.1274b32-41.

20 Peter Green, Alexander to Actium: The Historical Evolution of the Hellenistic Age, University of California Press, California, 1st edition, 1993, p. 29.

21 Ibid, p. 30.

22 Rafey Habib, 'Identity and Difference: Plato and Aristotle on Democracy', The University College of Ripon and York, 1998, available at https://habib.camden.rutgers.edu/talks/plato-and-aristotle/, accessed on 25 July 2020.
} 
chaos, as the freedom to exercise free will at the cost of breaking law and order was deemed to be the norm. ${ }^{23}$ Freedom would become the ultimate desire, replacing the prudent end-goal of having lived a virtuous and fruitful life that was true to a human being's existence. $^{24}$

Human life is plagued by instability. As a species, we desire a modicum of stability in our lives and depend on some form of authority for human flourishing. This authority is obeyed as people are fearful of the consequences that follow from contesting the power of the magnitude necessary for maintaining peace in society. Thomas Hobbes provided that human beings have certain characteristics that continually draw them into mutually destructive conflict with one another and the only way to cope with it is through the institution of the State. ${ }^{25}$ Hobbes believed that political order is possible only when human beings abandon their natural condition of judging and pursuing what seems best to each and delegate this judgment to someone else. This delegation occurs when the subjects submit to the sovereign's authority, in return for physical protection and a measure of well-being. Hobbes considered that it was best that the subjects transferred their right of governing themselves to the sovereign and obeyed the sovereign in all situations, except where the sovereign failed so miserably in his governance that the subjects feared for their safety. In such a situation, the subjects' obligations to obey the sovereign's orders would cease to exist. ${ }^{26}$

Aristotle further believed that the existence of a State directly corresponds to the health and virtue of an individual and that a State's purpose must always be to promote the collective good, which could be termed as the textbook definition of State. In contrast, modern-day definitions are far from characterizing a State through what it ought to do, and instead lay emphasis on what lies in the State's power- what it can do. This is portrayed in Max Weber's consensually accepted definition, where he expresses a State to be a human community that successfully claims the monopoly of the legitimate use of physical force within a given territory. ${ }^{27}$ The visible shift of focus can be disillusioning due to such a blatant change in the State's interests. However, the perception of a State is to practically be elements of both definitions. One cannot exist without the other, as to fulfill its purpose of promoting communal harmony and virtues, use of force may be required; and for that use of force to be justifiable, the citizens must be guaranteed collective good. Evidently, the State as an instrument is single-handedly responsible for ensuring the upkeep of society and the nation.

23 Ibid.

24 Naomi Reshotko, 'Socrates and Plato on 'Sophia, Eudaimonia', and Their Facsimiles', History of Philosophy Quarterly p.1, volume 26:1, 2009, p. 2; Howard J. Curzer, 'The Supremely Happy Life in Aristotle's Nicomachean Ethics', Apeiron p.47, volume 24:1, 1991, p. 49.

25 Thomas Hobbes, Leviathan, J. M. Dent \& Sons, London, 1914, p. 96; Robert Ladenson, 'In Defense of a Hobbesian Conception of Law', Philosophy \& Public Affairs p. 134, volume 9:2, 1980, p. 140.

26 Ibid, p. 103; Tom Sorell, 'Thomas Hobbes', Encyclopedia Britannica, 2020, available at https://www. britannica.com/biography/Thomas-Hobbes, accessed on 28 July 2020.

27 Max Weber, 'The Theory of Social and Economic Organization', in A. M. Henderson \& Talcott Parsons (eds), Max Weber: The Theory of Social and Economic Organization, The Free Press, New York, 1947, pp. 129198. 
While modern-day definitions and connotations of democracy have certainly evolved into a State that allows its subjects to elect their representatives and has proved to be the desired form of government, capable of sidestepping the need for war, one might argue that the lengthy process of decision-making required in a democracy, coupled with the need of public approval, has proved to be less than favorable in the hour of need of a global pandemic. Further, bearing in mind that democracy was conceptualized concerning a 'responsible' citizen who must whole-heartedly fulfil their obligations to the State, the deterioration of democracy in its true sense has been on the rise. The theory of 'political obligation' that underlines a democracy can be attributed to Socrates originally, however, a more concise version of it exists in the form of the 'social contract' as theorized by Thomas Hobbes and John Locke. ${ }^{28}$ Once the citizens of a State confer their consent to be governed rightfully and morally, they inherently agree to obey the State unless the laws laid down by it are visibly unjust. Thus, for a democracy to exist equitably, reciprocity is necessary. Arguably, in recent times, both the parties of this 'contract' can be seen to be lacking in their responsibilities and in fulfilling their end of the bargain. An investigation into state-led responses to past pandemics paints a clear picture of the role of self-interest in the decision-making of a government body — even to the extent of sacrificing its people for achieving the same.

\section{State-led Responses to Past Global Crises}

The infamous Spanish Flu that spread across the globe over a century ago and its poor treatment by states capture the bleak prospects of upholding the beliefs of a considerate and egalitarian government. With the First World War in action accompanied by a lack of freedom of the press; reports or warnings of any influenza outbreak were hindrances to the furtherance of the 'national interest', which in this case was supplying soldiers, medical personnel, and other resources, to emerge victorious in the war. ${ }^{29}$ It is not only disillusioning but also highly dangerous how the US and the UK Governments occupied themselves with the politics of the disease instead of its deadly consequences, as they refused to broadcast the epidemic and denied its existence. ${ }^{30}$ Citizens were openly encouraged to continue engaging in war efforts, and it was felt that such alarming news would demoralize and subsequently, prevent the people from doing so. ${ }^{31}$ It was only when the Flu reached a neutral state, which is Spain, were the masses made aware of a life-threatening disease among them, spreading as rapidly as

\footnotetext{
28 Paul Russell \& Jean Hampton, 'Hobbes and the Social Contract Tradition', Journal of the History of Philosophy p. 620 , volume $27: 4,1989$, p. 621.

29 Martin Karlsson, Therese Nilsson \& Stefan Pichler, 'The impact of the 1918 Spanish flu epidemic on economic performance in Sweden: An investigation into the consequences of an extraordinary mortality shock', Journal of Health Economics p.1, volume 36, 2014, pp. 2-3.

30 Mark Osborne Humphries, 'Paths of Infection: The First World War and the Origins of the 1918 Influenza Pandemic', War in History p.55, volume 21:1, 2014, pp. 55-81; Howard Phillips, 'The Re-appearing Shadow of 1918: Trends in the Historiography of the 1918-19 Influenza Pandemic', Canadian Bulletin of Medical History p.121, volume 21:1, 2004, p. 57.

31 Mark Honigsbaum, 'Regulating the 1918-19 Pandemic: Flu, Stoicism and the Northcliffe Press', Medical History p.165, volume 57:2, 2013, p. 170.
} 
the Bubonic Plague. By then, thousands had already become victims of what would be known as one of the deadliest epidemics the world had ever witnessed, killing a disputed 50 million people in its wake. ${ }^{32}$

It is safe to say that the initial reluctance in disclosure along with the lack of medical advancements at the time made the Flu what it had become. The prioritization of establishing a firm footing politically by the war-involved governments, against the upkeep of the lives of their subjects, cost the world a third of its population.

The Influenza Pandemic unearths yet another interesting perspective on the study of governmental interests. It resulted in the association of such pandemics with war and had started to be viewed as a means of destruction should a nation have the resources to cause it on another, with some scientists even explicitly referring to it as a "war disease." 33 The capacity of Influenza to devastate military forces had long been known to the governments, however, only after the Spanish Flu did they consider the possibility of it being used as a biological warfare weapon. This led to an increased State interest in preparing vaccines for the future. So convinced were some officials that Influenza would appear with the outbreak of World War II, that in 1941, the US established the Commission on Influenza of the United States Army Epidemiological Board to provide technical advice and commence work on an effective vaccine. ${ }^{34}$ Yet when the speculation bore no fruit, Influenza studies dropped just as fast as they had begun. By the mid-1980s, the pandemic Influenza had effectively fallen off the international agenda. ${ }^{35}$ Various factors can be attributed to this, predictably most of them concerning political interests. With the rise of nuclear warfare and its threats being more apparent compared to bioweapons as witnessed in World War II, the Governments were quick to shift their focus.

Any global crises, be it wars or pandemics, have a blunt way of highlighting governmental agendas and the state of the world at large. The post-World War II world saw the rise of the Allied Powers, with the US at the very forefront of it all; and with the creation of a Trans-Nation for world peace, it was clear that policies favoring these States would prevail worldwide. At the pretext of avoiding war, the United Nations (UN) gained increased legitimacy from the consent of the world nations and was known as a 'collective' effort of enforcing, what were otherwise US-led policies, namely, liberalism and free trade. ${ }^{36}$ Obvious furtherance of its economic viewpoint and profitability at the cost of most of the world, largely consisting of developing nations at the time, the UN seemed to forget that the said nations would not be as well-off as to welcome a free-

32 Adam Kamradt-Scott, 'Changing Perceptions: of Pandemic Influenza and Public Health Responses', $A M$ J Public Health p.90, volume 102:1, 2012, p. 90.

33 Ibid, pp. 90-98.

$34 \quad$ Kamradt-Scott (n 32), p. 92.

35 Ibid, p. 93.

36 Mat Burrows \& Peter Engelke, 'What World POST-COVID-19?: Three Scenarios', Atlantic Council, 2020, p. 6, available at https://www.jstor.org/stable/resrep24634?seq=1\#metadata_info_tab_contents, accessed on 29 July 2020. 
trade policy with open arms. ${ }^{37} \mathrm{It}$ is no surprise that this disparity between the dominant western countries and the third world is still very much intact, as the latter lacked resources for proper representation in international forums. ${ }^{38}$ Thereby, the interests of any government, whether it be national or international, are liable to be questioned.

\section{Authoritarianism and Populism in the Time of COVID-19}

\section{On authoritarianism}

Authority involves uncoerced obedience wherein persons subjected to it retain individual freedom. Authoritarianism, on the other hand, refers to the 'enforcement or advocacy of strict obedience to authority at the expense of personal freedom. ${ }^{39}$ The global pandemic demanded that the public cede several of their rights willingly in the protection of their existence. It is thus important to consider how the notions of 'authority' and 'authoritarianism' may assume different meanings in the current global scenario when our very lives are at stake.

Authoritarianism generally carries a negative connotation as it favors absolute obedience to authority and stands against individual freedom. ${ }^{40}$ Hannah Arendt, however, has pointed out that obedience is common to the notions of both authority and violence, which often gives rise to the notion that authoritarianism is violent. In this regard, she remarked that the liberals tend to identify totalitarianism with authoritarianism and are inclined to see totalitarian trends in every authoritarian limitation of freedom, thereby confusing authority with tyranny and legitimate power with violence. ${ }^{41}$ She underscores the difference between tyranny and an authoritarian government by laying down that the tyrant rules as per his own will and interest, whereas even the most draconic authoritarian government is bound by laws. This distinction becomes important, amidst the global pandemic, as the very way in which authority is understood is changing. Arendt's claim that 'practically as well as theoretically, we are no longer in a position to know what authority really is ${ }^{42}$ rings true now more than ever. Robert Mayer likewise highlights the benefits of authoritarian regimes and provides how they are categorized as non-democratic, simply because democracy is defined in a specific way. He considers how alternative conceptions of democracy can justify authoritarian rule based on the

\footnotetext{
37 Thamil Venthan Ananthavinayagan, 'Uniting the Nations or Dividing and Conquering? The United Nations' Multilateralism Questioned-A Third World Scholar's Perspective', Irish Studies in International Affairs p.35, volume 29, 2018, pp. 35-51; Michael Byers et al, 'VOICES FROM THE OUTSIDE: SOVEREIGN EQUALITY, INTERNATIONAL LAW, AND THE IMBALANCE OF POWER', Proceedings of the Annual Meeting (American Society of International Law) p.43, volume 99, 2005, pp. 43-55.

38 Byers et al (n 37), p. 50.

39 'authoritarianism', Lexico: Powered by Oxford, available at https://www.lexico.com/en/definition/ authoritarianism, accessed on 30 July 2020.

40 Bruce Romanish, 'Authority, Authoritarianism, and Education', Education and Culture p.17, volume 12:2, 1995, p. 18.

41 Hannah Arendt, 'What is Authority?', Between Past and Future, The Viking Press, New York, 1961, p. 97.

42 Ibid, p. 92.
} 
principles of unequal competence, unequal stake, and unequal standing. ${ }^{43}$

A surge in authoritarianism is observed across the world with the advent of COVID-19, evident through the enforcement strategies adopted by the heads of various nations to prevent the spread of the virus. It may be relevant to contemplate exercising authoritarian rule under circumstances where the governed cannot be relied upon to decide what lies in the best interests of the general public. Such difficult decisions must thus be left in the hands of the sovereign authority. Responding to the global pandemic urges us to recognize a modern form of authoritarianism and it need not be conceived the way it traditionally has been.

\section{On Populism}

Populism is a moralistic political ideology, generally categorized as thin, as it neither constitutes a huge chunk of political agenda nor serves as a stand-alone ideology. The essence of populism is encapsulated in the way it uses people. Cas Mudde refers to it as the 'politics of the pub', involving a highly emotional and simplistic discourse that is directed at the 'gut feelings' of the people. ${ }^{44}$ While described differently by various scholars, the ideology is constituted by two categories- 'the elite' and 'the people'. It considers society as ultimately separated into these two homogeneous, antagonistic groups and propounds that politics should be an expression of the 'general will' of the people. ${ }^{45}$

Populism thus involves reordering the existing political establishment so that the leadership comes to reflect the 'general will' of the people in terms of their desires, needs, and aspirations, rather than those of 'the elite', who are inherently corrupt and motivated only by self-interest. ${ }^{46}$ Once the 'general will' has been expressed, the public is expected to leave governance to the leader who has been elected due to his 'superior capacity to discern the common good, as supposedly judged and willed by the public. ${ }^{37}$

Central to the operation of populism is a personalized leader who activates an antiestablishment cleavage by appealing to 'the people', who do not pre-exist as a community, but which he molds, based on conditions of no-confidence, disenchantment or alienation from politics. ${ }^{48}$ The uniformity and centrality of the people, anti-elitism, use of the tools of direct democracy, creation of an external enemy, amplification of a 'crisis', direct style of communication aimed at simplifying complexity, and use of the

43 Robert Mayer, 'Strategies of justification in authoritarian ideology', Journal of Political Ideologies p. 147, volume 6:2, 2001, p. 149.

44 Cas Mudde, 'The Populist Zeitgeist', Government and Opposition p.541, volume 39:4, 2004, p. 542.

45 Ibid, p. 543.

46 Jan-Werner Müller, 'The people must be extracted from within the people: Reflections on Populism', Constellations, p. 1, volume 21:4, 2014, p. 11.

47 Ibid.

48 Lorenzo Viviani, 'A Political Sociology of Populism and Leadership', SOCIETÀMUTAMENTOPOLITICA p.279, volume 8:15, 2017, p. 289. 
image of the leader as an outsider are common to populist ideology. ${ }^{49}$

Populism generally becomes active only when there are special circumstances, in the form of a crisis. ${ }^{50}$ COVID-19 is the latest crisis that plagues the human condition. Populist strategies are being adopted by several leaders of states to fight the pandemic. ${ }^{51}$ It is important to remain wary of the measures being taken and guard against populist State tendencies in the post-COVID world, as a global crisis such as the pandemic provides fertile ground for populism to thrive and proliferate. The notion of authority, and in turn, authoritarianism, must be understood in such a context to help situate the role of populism and how it might influence the political setup of the post-COVID world.

\section{Perspectives on the Post-COVID World}

Having discussed the key theories that could be the determinants of the future, it is essential to take note of their nature as double-edged swords; as with increased legitimized power, governments are sanctioned to potentially make or break what is yet to come. As a thin-centred ideology, populism can easily be combined with other ideologies, such as nationalism. Populism and nationalism both focus on the 'who' of politics. ${ }^{52}$ Populist forms of leadership insist that they represent the entire nation and assume control of the entire state apparatus in the name of 'the people' grounded in appeals to nationalism. ${ }^{53}$

We propose that the populist strategies adopted by heads of States have not only emphasized the primacy of the State in tackling the pandemic but are also fueling a particular brand of nationalism targeting minorities and marginalized communities. ${ }^{54}$ This results in what Patricia Williams refers to as 'spirit murder' or the utter disregard for others whose lives qualitatively depend on our regard. She provides that it produces a system of formalized distortions of thought and produces social structures centered on fear and hate. ${ }^{55}$ An 'exclusionary nationalism' is thus a major consequence of such populist strategies adopted by leaders. It is highly polarizing and divisive and, when combined with populism, denies the legitimacy of alternative political positions.

Likewise, exclusionary nationalism and authoritarianism enjoy a symbiotic relationship. ${ }^{56}$

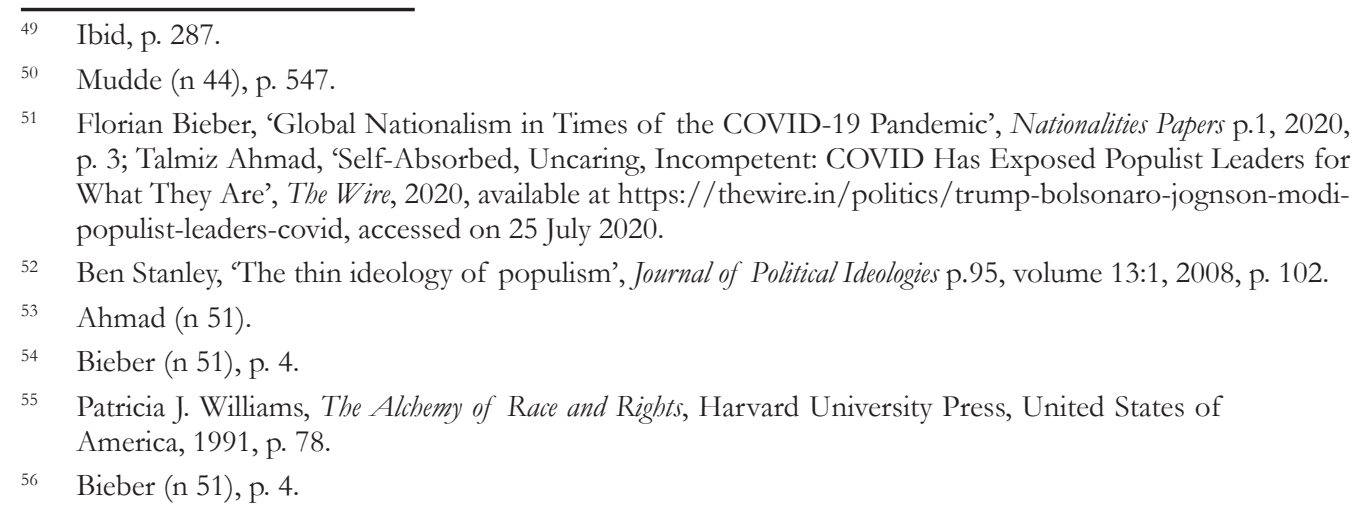


This form of nationalism has strong authoritarian themes, as it emphasizes the importance of the collective nation over individuals. We may also refer to Agamben's inclusive exclusion ${ }^{57}$ (signifying a double movement- capturing at the very moment of exclusion) to understand such a form of nationalism. For him, Western politics is founded upon that which it excludes, and sovereignty insists on capturing what lies outside of the political order, establishing itself through the production of a political order based on the exclusion of bare, human life, transformed in relation to sovereign power (into a bare life without rights). ${ }^{58}$

There is a long-established pattern of linking minorities, racial groups, and specific communities to disease. ${ }^{59}$ In the Indian context, a surge in the cases of anti-Muslim attacks was observed when a gathering of the Tablighi Jamaat, the multinational Muslim missionary movement, was identified as being responsible for a large share of India's COVID-19 cases in April 2020.60 The movement was repeatedly blamed by the Ministry of Health and Family Welfare (MoHFW) for spreading COVID-19 and terms such as "human bombs" and "corona jihad" gained currency across the country, spewing religious hatred against the Islamic community in India. ${ }^{61}$ Likewise, Cynthia Miller-Idriss points out that COVID-19 is likely to amplify existing ethnic and national cleavages across the world. She provides that while rising xenophobia, conspiracy-fueled anti-Asian and anti-Semitic violence, and anti-immigrant hate can already be observed in the West ${ }^{62}$, the Global South will also be affected owing to the lack of trust between local communities, governments, and international organizations. Such an ethnic and populist brand of nationalism increases the risks of conflict with individuals and communities who are perceived as 'others ${ }^{963}$. Miller-Idriss refers to this as 'populist nationalism'. ${ }^{64}$

Populist nationalism extends the 'pure people-corrupt elite' dichotomy to a framing in which all 'others' pose an essential threat to the nation and the public. It is portrayed that only a stronger State can protect the nation from the growing dangers posed by

57 Giorgio Agamben, Homo Sacer: Sovereign Power and Bare Life, translated by Daniel Heller-Roazen, Stanford University Press, Stanford, 1998, p. 21.

58 Ayten Gündoğdu, 'Potentialities of human rights: Agamben and the narrative of fated necessity', Contemporary Political Theory p.2, volume 11:1, 2012, p. 6; Amy O’ Donoghue, 'Sovereign Exception: Notes on the Thought of Giorgio Agamben', Critical Legal Thinking, 2015, available at https:/ criticallegalthinking. $\mathrm{com} / 2015 / 07 / 02 /$ sovereign-exception-notes-on-the-thought-of-giorgio-agamben/, accessed on 28 July 2020.

$59 \quad$ Bieber (n 51), p. 6.

${ }^{60}$ Akash Bisht \& Sadiq Naqvi, 'How Tablighi Jamaat event became India's worst coronavirus vector', Aljazeera, 2020, available at https://www.aljazeera.com/news/2020/04/tablighi-jamaat-event-india-worstcoronavirus-vector-200407052957511.html, accessed on 28 July 2020.

61 Jeffrey Gettleman, Kai Schultz \& Suhasini Raj, 'In India, Coronavirus Fans Religious Hatred', The New York Times, 2020, available at https://www.nytimes.com/2020/04/12/world/asia/india-coronavirus-muslimsbigotry.html, accessed on 25 July 2020.

62 Eric Taylor Woods et al., 'COVID-19, nationalism, and the politics of crisis: A scholarly exchange', Nations and Nationalism p.1, volume 26:4, 2020, p. 11.

63 Ibid.

${ }^{64}$ Woods et al. (n 62), p. 10. 
such 'others'. The 'savages-victims-saviors' metaphor in human rights discourse also presents the State as an instrument of savagery, in so far as it either acts as a good State, casting out evil and ousting it from civil society, or a bad State, characterized by an illiberal, anti-democratic, or other authoritarian culture. ${ }^{65}$ This very construction, however, is criticized as resulting in pitting the 'savages' against the 'victims' and the 'saviors' ${ }^{66}$ Likewise, Woods also provides that such a process of othering, the search for blame, and the calls to protect our 'own' are driving a dynamic whereby foreigners and immigrants are being targeted in many states. ${ }^{67}$

When the public is prone to fixate on a given fear, that fear becomes the most effective channel of communication. The impact of mass fear results in the citizenry calling for government leaders to take decisive action, which in turn requires ceding control in the hope of gaining protection, as has been observed amid the global pandemic. Andy Williams perceives such an increasing level of control by the state as having a hidden cost in terms of human lives because no system of collective intelligence exists to ensure that the decisions made with all that power given up by the citizenry will be in their best interests. ${ }^{68}$ Ajnesh Prasad, likewise, describes how the 'organization of ideological discourse' is utilized by populists to craft social realities aligned to their own political and ideological aspirations. He believes that this prevents a critical examination of how the very discourses over COVID-19 are discreetly being packaged to accomplish problematic ideological aims. ${ }^{69}$ Authoritarianism, populism, and nationalism are thus closely interlinked and often mutually reinforcing.

The essay so far has elaborated upon the various ideological and systematic shifts that may occur in the organization of the State and on the public's varying perception of it. The current trend seems to indicate an increasing acceptance of the finality of governmental decision-making, even if it deviates from the previously conventional view on liberty and freedom and their importance. An example of this is the global praise received by China in dealing with the virus, as its authoritarian nature allowed it to impose highly restrictive measures on its citizens that ultimately were the driving force behind successfully rendering COVID-19 as a thing of the past. ${ }^{70}$ China was back to its full productivity while working towards taming the massive decline caused in its economy due to the pandemic. A stark comparison can be drawn here with the democratic states of the US and India, wherein the harsh realities of incompetency and failure to execute stringent and rigorous policies for the required period have started

\footnotetext{
65 Makau Mutua, 'Savages, Victims, and Saviors: The Metaphor of Human Rights', Harvard International Law Journal p. 201, volume 42:1, 2001, p. 203.

$66 \quad$ Ibid, p. 205.

${ }_{67}$ Woods et al. (n 62), p. 15.

68 Andy E. Williams, 'COVID-19 and The Hidden Cost of Reduced Civil Liberties', 2020, available at https://osf.io/preprints/socarxiv/scnza/download, accessed on 4 July 2020.

69 Ajnesh Prasad, 'The organization of ideological discourse in times of unexpected crisis: Explaining how COVID-19 is exploited by populist leaders', Leadership p. 294, volume 16:3, 2020, p. 300.

70 Liu Xiaoming, 'China has valuable lessons for the world in how to fight COVID-19', Financial Times, 2020, available at https://www.ft.com/content/ad61f0ea-8887-11ea-a109-483c62d17528, accessed on 29 July 2020 .
} 
to creep in. Owing to their structure as Democratic Republics as well as Federations, the scramble to find a balance between approval from each State head along with the citizens and the efforts of eradicating the disease has proved to be counterproductive.

With the US population being quick to exercise its rights in any given situation, nationwide protests, lockdowns, and wearing masks have taken a toll on how the country has been faring in the global COVID charts- with an end nowhere in sight. However, the path to authoritarianism is far from being a linear one and works in favor of the people only when combined with accountability. In the context of China's plight yet again, having dealt with its internal problems, it faces alienation from the world due to the alleged similar outlook it had on disclosure of facts as the Allied powers during World War I. Being the place of origin of the virus, the weight of the failure to inform the world about the potential risks of a highly infectious disease that had begun to spread in its territory, China is facing severe backlash and contempt from the nations still struggling to cope with the escalation of COVID-19. This can be observed in US President Donald Trump's persistent insistence on referring to 'Coronavirus' as the 'Chinese virus. ${ }^{71}$ The lack of transparency has caused the seeds to be sown of an oust against China from any international economic trading, where countries such as India have placed a ban on Chinese ventures.

A post-COVID world may very well be deserving of being termed as a new epoch, not as much for the disease itself as for its implications. Resistance is futile, and we must embrace these sudden changes with a balance between faith and awareness, and since the pandemic has proven that an overthrow of the State is not an option, it has also displayed how the power can truly lie with the people if they are keen enough to use it - whether it be in the forms of demands of transparency, protesting (for the right reasons), or even simply fulfilling their moral obligations to one another. While we, the people, have accepted restrictions and curtailing of some of our freedoms, we still retain enough morality to push back and bring down a government/leader who will try to push overtly repressive policies down our throats. At the same time, we will accept more restrictions than before (on movement and closure of certain categories of businesses, among others) and will be more willing to accept a greater presence of the State in our lives.

\section{Conclusion}

'All that is solid melts into air, all that is holy is profaned, and man is at last compelled to face with sober senses, his real conditions of life, and his relations with his kind. ${ }^{72}$

The Communist Manifesto was first published in London by a group of German-born revolutionary socialists known as the Communist League in 1848. This essay is being

\footnotetext{
${ }_{71} \quad$ Katie Rogers, Lara Jakes \& Ana Swanson, 'Trump Defends Using ‘Chinese Virus’ Label, Ignoring Growing Criticism', The New York Times, 2020, available at https://www.nytimes.com/2020/03/18/us/politics/ china-virus.html, accessed on 30 June 2020.

72 Karl Marx \& Friedrich Engels, The Communist Manifesto, Penguin Random House, London, 2018, p. 27.
} 
written in 2020. More than a century and a half have passed, and one can still find themselves resonating with the sentiment reflected in the above quote by Marx.

This essay attempted the provision of a perspective on some of the political implications of COVID-19. The detailed analysis of State behavior in times of global crises is an attempt to highlight the cracks in the system that showcase themselves at their worst during times when the reliability of that very system is at its peak. It evidently took varied forms of a regime wherein the Governments prioritized safeguarding the lives of their respective nations instead of the lives of the citizens themselves. Drawing from the ancient philosophers' conception of a citizen-servant State followed by describing contrasting concepts such as authoritarianism and populism; the aim was to put in perspective the theoretical versus the practical perceptions of the State machinery. This was done in hopes of understanding this gap and how the bleak reality that citizens currently face might be alleviated. An analysis of the interplay between the ideologies of authoritarianism, populism, and nationalism indicates that the post-COVID world could result in increasing disparities for the marginalized. While authoritarian regimes might initially rely on the pandemic to justify repressive policies, they are likely to turn to exclusionary nationalism as a key legitimizing ideology to sustain power in the post-COVID world. ${ }^{73}$ Yet, in the last section, this paper deflects as little responsibility as possible to those in power and desires to convey the urgency of practicing accountability — the onus being not just on the mighty but also on the meek. Citizens themselves must ensure actions are undertaken with the consideration of the highest good, and fundamental rights such as the right to protest or freedom are not misused at the cost of their fellow human beings.

The global pandemic has shaken the foundational notions that characterize modern society. A host of rights that dignify our life have had to be sacrificed. The new normal resembles life that is reduced to mere existence to a severe extent. Moving into the post-COVID world, we must critically appraise our condition. The veil of the pandemic, forged out of uncertainty and fear, must be lifted from over the pre-existing vulnerabilities that plague humankind and from the ideological mystifications ${ }^{74}$ being weaved by populist leaders in this time of crisis. It may be well to consider COVID-19 as a wake-up call for historical retrospection. ${ }^{75}$ We suggest that the pandemic must be viewed as an invitation, if not a provocation, to transform the crisis into an opportunity for the construction of a system that will be just, inclusive, and fair for the many. A crisis need not lead to a permanent expansion of government powers if the public remains vigilant. ${ }^{76}$ Interferences with fundamental human rights must be viewed with caution, if not suspicion, and must strictly be limited to what is required to tackle the

\footnotetext{
Bieber (n 51), p. 4.

74 Slavoj Žižek, 'Is Barbarism with a Human Face Our Fate?', Critical Inquiry, 2020, available at https:/ / critinq. wordpress.com/2020/03/18/is-barbarism-with-a-human-face-our-fate/, accessed on 22 June 2020.

75 Manoj Kr. Bhusal, 'The World After COVID-19: An Opportunity for a New Beginning', International Journal of Scientific and Research Publications p.735, volume 10:5, 2020, p. 739.

76 Alexandra Wrage, 'The Pandemic Will Be a Boon for Good Government', Foreign Policy, 2020, available at https://foreignpolicy.com/2020/05/16/future-government-powers-coronavirus-pandemic/, accessed on 4 July 2020.
} 
pandemic. State measures and policies should not be used to promote power grabs, quash dissent, or persecute minorities. ${ }^{77}$ Global solidarity may take a blow, given the inward movement of respective States, but that need not mean a return to some premodern, pre-technological state where we cling to the bosom of nationalism. ${ }^{78}$ It may be wise to inspire ourselves with the words of Yanis Varoufakis in his Introduction to The Communist Manifesto,

'In the end, what prevails is up to us. ${ }^{79}$

77 Alessandra Spadaro, 'COVID-19: Testing the Limits of Human Rights', European Journal of Risk Regulation, p. 317, volume 11:2, 2020, p. 323.

78 Yanis Varoufakis, 'Yanis Varoufakis: Marx predicted our present crisis - and points the way out', The Guardian, 2018, available at https://www.theguardian.com/news/2018/apr/20/yanis-varoufakis-marxcrisis-communist-manifesto, accessed on 03 August 2020.

79 Marx \& Engels n (72), p. xxix. 